DOI 10.14746/ssp.2020.3.6

Nađa Beglerović

Masaryk University

ORCID: 0000-0003-1909-7263

\title{
Milorad Dodik's Use of Contentious Rhetoric in (De)constructing Bosnia and Herzegovina's Identity: A Discourse-Historical Analysis ${ }^{1}$
}

\begin{abstract}
The article explores Milorad Dodik's rhetoric and nationalist discourse in Bosnia and Herzegovina $(\mathrm{BiH})$. It seeks to shed light on the intricacies of the politics of the current Serb member of the tripartite Presidency of $\mathrm{BiH}$ by analyzing a number of television interviews and the speeches Dodik delivered at the celebration of the RS Day on January 9, 2017-2020. Unfortunately, BiH continues its struggle with divisive identity politics, which perpetuates the nationalist paradigm of the nation. Identity politics plays an integral part in the construction of "we" versus "them," and underlies the lack of a "national identity." The analysis will reveal Dodik's political strategies and offer a glimpse into his ideology and views of $\mathrm{BiH}$ as well as his vision and long-term objectives for the Republika Srpska (RS). Moreover, the article examines linguistic practices and seeks to answer the following research questions: how does Dodik view $\mathrm{BiH}$, and what are his long-term goals for RS? Has identity politics influenced the emergence of referendums in RS? What could the referendums proposed and already held in the RS mean for the future of $\mathrm{BiH}$ and its national identity?
\end{abstract}

Key words: referendum, national identity, identity politics, discourse-historical analysis, Bosnia and Herzegovina, Milorad Dodik

\section{Introduction}

This paper examines the coherence of Dodik's rhetoric about Bosnia and Herzegovina $(\mathrm{BiH})$ and the Serb Republic (RS), his long-term goals, and the role the "Referendum on the Day of RS" has played and may play in the future. The aim of the paper is to analyze the content and qualities of Dodik's rhetoric in light of his interviews and speeches at the celebration of RS Day from 2017 to 2020. The selected interviews and speeches will be further elucidated in the data section of the paper and

1 The paper was written as part of the research project "Perspektivy evropské integrace v kontextu globální politiky II” at Masaryk University (MUNI/A/1044/2019). 
are meant to answer the following research questions: How does Dodik perceive $\mathrm{BiH}$ and what are his long-term goals for RS? Have identity politics influenced the emergence of referendums in the RS? What could proposed and already held referendums in the RS mean for the future of $\mathrm{BiH}$ and its national identity?

After serving his second term as the President of RS, Dodik ran for the Serbian seat of BiH's tripartite presidency in the 2018 election and won. Dodik's victory has further emboldened him to make questionable and unfettered rhetoric about $\mathrm{BiH}$. He has openly argued for RS interests and independence, which has undermined BiH's national identity and has brought the future of $\mathrm{BiH}$ into the question. Despite being one of the main antagonists of a united $\mathrm{BiH}$, Dodik is now its representative.

Dodik has often described $\mathrm{BiH}$ as a burden with no future, "something we [Serbs] want to shake off our back" (Vujanovic, 2010). Moreover, Dodik stated, "our freedom is our country, and our country is RS" (IndexHr, 2018). According to Dodik, the new government can define the long-term status of RS. Thus, it is crucial to further explore the development of Dodik's political discourse.

The discourse-historical approach (DHA) is employed in the analysis because it incorporates different genres of discourse related to the issue. By focusing on the content, as one of the three dimensions of DHA, one can systematically portray the discursive construction of national identities, address the creation of nationalist ideology, the discursive construction of a shared culture, the political present and future, and the national body, as well as describe and create its shared political past (Wodak, 2016). Moreover, DHA is meant to "trace the intertextual history of phrases and arguments" (Blommaert, 2005, p. 28). Special attention is given to the discursive construction and representation of "us" and "them." Ciepley (2013) discusses the danger of political candidates using identity politics in multiethnic and multi-religious democracies as this can lead to "us" versus "them" (p. 137). Lastly, identity politics need to be taken into consideration.

\section{A Brief Overview of BiH's Political Set Up and Its Impact on Identity Formation}

Ever since the breakup of Yugoslavia and BiH's declaration of independence, fragmented and unstable national and ethnic identities emerged 
in $\mathrm{BiH}$. Like Austria, which faced challenges with its national identity as the result of geopolitical transformation in 1989, $\mathrm{BiH}$ has been dealing with the dilemma of how to maintain and transform its national identity. Today, there still appears to be a struggle between the ethnic and national identities within $\mathrm{BiH}$. The complex territorial and political structure of $\mathrm{BiH}$ requires us to look at the dimensions of the discursive construction of ethnic and national identities. ${ }^{2}$

$\mathrm{BiH}$ consists of two entities - the Federation of $\mathrm{BiH}$ (Federacija $\mathrm{BiH}, \mathrm{FBiH}$ ) and the Serb Republic (Republika Srpska, RS) and, additionally, the autonomous district of Brčko. The international community contributed to $\mathrm{BiH}$ 's status as a de facto protectorate, known for its loose federation and weak central government (Bieber, 2006, p. 40). Its current political system was established by the Dayton Peace Agreement (DPA), which ended the war in 1995. While it stopped the war, the DPA also "institutionalized an ethno-territorial division of $\mathrm{BiH}$ organized around war territories, locking nationalist antagonism into the very structure of the state" (Toal, 2013, p. 199). Unfortunately, the ethno-territorial division could have attributed to the recreation of the hatreds (Holbrooke, 1999). According to Gromes (2010), "at least one party to the conflict rejected the concept that its own ethnic group would constitute a single sovereign political community together with its rivals. Consequently, the sense of being a common nation was missing" (p. 360). Moreover, Basseuner (2009) argues that the country's constitution, the Annex IV of DPA, "generates new nationalists by making fear and ethnic divisiveness politically profitable" (p. 197).

Like in many war-stricken countries, $\mathrm{BiH}$ and its different ethnic groups have struggled to address the consequences of the war and agree on the narratives of the past. Unfortunately, this has impacted the creation of its national identity and left $\mathrm{BiH}$ in the hands of the political elite to portray the identity in a way that will further their own political agenda. Instead of framing a national identity, some political elites have concentrated on ethnic polarization instead. Thus, $\mathrm{BiH}$ is marred by weak institutions, as a result of ethnic politics, and its attempts to unify its citizens are derisory.

${ }^{2}$ Wodak et al. (1999) developed a method of description and analysis to examine the discursive production of national identity by using an Austrian case study, which can be applied to other countries. 


\section{Milorad Dodik, referendums, and their danger to BiH statehood}

During his political career, which began in 1998, Dodik has undergone a political metamorphosis, drastically changing his political ideologies and political orientation. At first, Dodik presented himself as a moderate Bosnian Serb, a protagonist of Serb nationalist politics and a supporter of a pragmatic technocratic wing of politics. Dodik appeared to be committed to peace building, reconciliation, and national unity. While Washington and Brussels considered him the biggest political breakthrough since DPA, pro-Karadzic supporters inveighed against Dodik and viewed him as "a tool of the West who betrayed Serbs" (Jeffries, 2003, p. 28).

Between 2001 and 2005, Dodik and his political party, the Alliance of Independent Social Democrats (SNSD), inordinately changed its political rhetoric. In 2005, during the negotiations on constitutional reform, it was revealed that $\mathrm{SNSD}$ envisioned $\mathrm{BiH}$ to resemble the former Yugoslavia, a federalized state with two or more entities/republics, which would have the right to self-determination. Dodik has managed to engineer the de facto autonomy of the RS (Parish, 2011). Moreover, Dodik has begun stressing the Serb national identity and undermining the Bosnian national identity. He has portrayed Serbs as victims, often silenced and disrespected by local and international authorities. Thus, Dodik has emerged as the chief protagonist of Serb nationalist politics (Maksic, 2009, p. 6). As such, Dodik has become the main obstacle for $\mathrm{BiH}$, as he thwarts reforms necessary for BiH's state-building in its quest for NATO and EU membership.

Referendums may become Dodik's main tool for strengthening his overall political power, while subverting the BiH's state-building trajectory. Talks about referendums might have been strategically used and manipulated by Dodik to garner legitimacy and improve his political standing, ultimately radicalizing the Bosnian political scene. While the crude application of the referendums, especially when used to settle territorial claims in such a complex multi-ethnic environment, may lead to precarious and perilous results, Dodik argues that referendums represent a democratic act guaranteed by the UN convention. Instead of being a legitimate democratic procedure, though, a direct vote empowering the electorate to approve or dismiss a particular proposal makes referendums in $\mathrm{BiH}$ contentious. Although the international community entreated Dodik to pull the plug on the referendum on RS Day, it was held and drew attention to BiH's immense structural problems. According to Dodik, "We [Serbs] will not hesitate to hold a referendum in the future on various issues, 
and therefore opponents believe that if this one is prevented, it would diminish the will of the Serbian people to fight further" (Alternativna TV, 2016). Toal (2013) argues that Dodik's rhetoric regarding the "referendum" is understood as the referendum which will lead to RS's secession from BiH. Dodik states, "Nobody can prevent us [Serbs] from holding a referendum. We never gave up on it, but everything has its time" (as cited in Barlovac, 2012). Many question whether this referendum could lead to others, including one about RS's secession from BiH, since Dodik has reiterated on multiple occasions that RS will use referendums in the future to decide various issues.

\section{Data selection and methods of analysis}

The Discourse-Historical Approach (DHA), which represents one of many theoretical and methodological approaches in Critical Discourse Analysis (CDA), is used to analyze Dodik's rhetoric. The approach was selected because of its level of research interest and methodological orientation towards identity construction and unjustified discrimination, the historical dimension of discourse formation, as well as for addressing identity politics (national, local, transnational, and global) and the politics of the past. DHA is problem-oriented and, as such, it aims to clearly address and analyze the complexity of the object/study under investigation. Thus, it integrates multiple approaches, incorporates different analytical perspectives, and utilizes various sources of data, making it interdisciplinary (Wodak, 2016). The researcher chooses the empirical data and sources most relevant to the problem in question (Wodak, 2009).

Wodak et al. (1999) discuss five major thematic areas of the discursive construction of national identity and the linguistic construction of (1) a homogenized national figure/individual as well as construction of the "self" and "others"; (2) common history (i.e. myths, past events); (3) common culture (i.e. religion, art, etc.); (4) common political standing (i.e. current situation and future ambitions); and (5) national territory. However, not all of these areas will be covered in detail in this article. Detecting the macro-topics and other subtopics will help uncover the purpose of a speech and determine what type of strategies and devices the speaker uses to accomplish the intended meaning with his/her speech.

By using DHA's three-dimensionality (i.e. identification of specific contents/topics of a specific discourse, investigation of discursive strate- 
gies, and examination of linguistic means), the study defines the terms used, integrates available information with the historical background, and analyzes the coherence of the texts. Although the terms "ethnicity" and "nationality" have sometimes been used interchangeably in the context of the former Yugoslavia, for the purpose of this study, the author applies Majstorovic and Turjacanin's (2012) definitions. The term "ethnic" is used when identifying Serbs, Croats, and Bosniaks while the term "national" is used with regards to state-related $[\mathrm{BiH}]$ identity. In addition, the author uses Wodak's (1999) definition of national identity, which states that "national identity is the product of discourse" (pp. 44-45).

According to Wodak, (1) nations are mainly mental constructs; (2) national identity consists of "a set of dispositions, attitudes and conventions that are largely internalized through socialization and create a national habitus;" and (3) nationhood represents a configuration of social identity, which can be "produced, transformed, maintained and dismantled through discourse" (Wodak, 2016, p. 8; Wodak et al., 2009, pp. 3-4). Wodak at al. $(2009$, p. 189) argue that the construction of a common culture as well as a "national character" is crucial in the discourses of national identity, as it adds value to the other "common" elements (i.e. past, present, future, territory, etc.). Selected definitions explain how individuals may relate to, believe in, and identify with the envisioned image of the imagined nation, which can be observed in the discourse and construction of Dodik's narratives of RS discourse culture, lack of desire for national [BiH] unity and absence of emotional connection with $\mathrm{BiH}$ as a state. Lastly, earlier research on national identity revealed that the way the political elites construed identity differed from how it was construed in everyday life (as cited in Majstorovic and Turjacanin, 2012, p. 40).

According to Wodak (2001), four types of discursive macro-strategies need to be applied in discourses about nations and national identities: constructive strategies; strategies of perpetuation and justification; transformation strategies; and destructive strategies. These strategies are a "more or less intentional plan of practices (including discursive practices) adopted to achieve a particular social, psychological or linguistic aim" (Wodak, 2001, p. 73). Each of these strategies has different objectives and by identifying them in the analysis, one gains a better understanding about identity formation and division between social groups (De Cillia et al., 1999; Wodak et al., 1999).

As stated by van Leeuwen and Wodak (1999), social actors use discourse to constitute information, situations, social roles, identities and 
interpersonal relations between different social groups. Their discursive acts play a critical part in the genesis, the production and construction of social conditions, national identities and/or groups of people (e.g. Serbian versus Bosnian, Serbs versus Bosniaks, Serbs versus international community). Moreover, these discursive acts are used to validate, reproduce, transform or eliminate the status quo (e.g. interpretation of DPA, international influence, etc.).

Reisigl and Wodak (2001) provide five discursive strategies which are all embroiled in the positive self- and negative other-presentation, and can assist in the analysis of discourses about racial, national and ethnic issues. They are strategies of reference/nomination (used to construct and represent social actors/in-groups and out-groups); predication (used to label social actors more or less positively or negatively, deprecatorily or appreciatively); argumentation (using topoi to justify positive and negative attributions); perspectivation, framing or discourse representation (used by speakers to address their involvement and point of view); and intensification and mitigation (used to qualify and adjust the epistemic status of a proposition) (pp. 44-47).

Rabushka and Shepsle (1972) emphasize the significance of the speeches of the political elite/presidents because they often tend to explicate the creation of either ethnic or national identity. Throughout his political career, Dodik has used public appearances, speeches, and interviews to run the gamut of political topics and convey messages to his constituents, supporters and opponents. He has demonstrated his ability to tailor his speeches to his audiences, either escalating or de-escalating his nationalistic views. Dodik's political rhetoric has been examined over time with special emphasis on the period between 2016 and 2020, as this time frame offers insight into the latest political agenda and ideas Dodik has endorsed. During this time the first referendum took place and Dodik's talk about future referendums, including the one on secession, intensified.

Dodik incorporates identity politics in his speeches. Thus, the author uses Benhabib's definition of identity politics, which states that "identity politics is always and necessarily a politics of the creation of difference" (1997, p. 28). The danger lies in the atavistic belief that one must eliminate difference and otherness in order to sustain and safeguard one's own identity. This leads to stereotypes and dichotomies about ethnic groups and results in the "us" versus "them" dichotomy.

This study consists of an analysis of three interviews with Milorad Dodik and four of his speeches. The selected interviews address Dodik's 
views on $\mathrm{BiH}$ and its future, the involvement of the international community, referendums, and secession. They were conducted after the referendum, after the celebration of RS Day, both before and after his election, and by a variety of journalists, both domestic and international - Senad Hadzifejzovic (Centralni Dnevnik - CD, BiH), Zorica Ilic and Bahri Cena (Deutsche Welle - DW, Germany), and Milomir Maric (Cirilica, Serbia). The selected speeches were given at the celebration of RS Day in 2017, 2018, 2019, and 2020.

\section{Dodik's rhetoric on Bosnia and Herzegovina}

Dodik's rhetoric has drastically changed during the period of 1997 1999 and 2000-present. Unlike his current opinion of BiH, in 1997, Dodik supported the concept of a united $\mathrm{BiH}$ stating, "It's better to be an entity in $\mathrm{BiH}$, than a province in Serbia" (as cited in Slobodna Bosna, 2016). Moreover, Dodik believed that "the Dayton-built $\mathrm{BiH}$, gives a better chance for their [Serbs'] development than if they were part of Serbia, which some nationalists hope to see" (as cited in BN, 2016). As his political rhetoric shifted, Dodik began to equivocate and prevaricate when speaking about $\mathrm{BiH}$. Lately, Dodik's rhetoric on $\mathrm{BiH}$ has become more hardline, divisive and ethno-nationalist. Dodik focuses primarily on Serbs' national politics and their identity. He has never promulgated a BiH identity while he has worked tirelessly for the RS. Dodik argues that the DPA created a union of two state-like entities that have precedence over $\mathrm{BiH}$, which itself was not defined as a "state," just given the name BiH (RS Day, 2017). This description of $\mathrm{BiH}$ makes it look as if $\mathrm{BiH}$ has the setup of the former Yugoslavia. Thus, Dodik does not talk about the BiH's national identity; instead, he discusses the RS's identity.

Analysis of Dodik's rhetoric reveals the use of four types of discursive macro-strategies. First, Dodik uses constructive strategies to establish a specific national identity, which can be argued to be the "Serbian" identity. Dodik openly identifies as a Serb from Banja Luka, RS, and if asked for further identification, he has declared himself as a Serb from Belgrade [Serbia] (Ivanji, 2009). During his interview with Maric, Dodik declared: "I am not a member of this Bosnian state and I do not identify with it. I am a member of the Serbian people and I have the citizenship of RS and Serbia. I only have a formal citizenship in $\mathrm{BiH}$, but it does not give me any pleasure" (Cirilica, 2018). Dodik does not identify as a Bos- 
nian and refers to it as an imposed identity and label. Dodik often uses the discursive construction of "we"/"us" [Serbs], and "them" [Bosniaks and the international community led by the U.S. and Great Britain]. By using the pronoun "we" together with a specific group, Dodik creates a national "we-group" and associates it with the toponymical label, which in this case is "The Serbs." Moreover, Dodik uses "we" as a linguistic tool to separate himself and Serbs ("we") from others. Thus, Dodik clearly defines and restricts "we" to Serbs living in the RS, as well as Serbs in Serbia. He uses ethnic polarization in his attempt to frame and foster the "Serb" identity. Moreover, by stressing the importance of unity and working together, while also emphasizing the difference between ethnic groups, Dodik is able to appeal to a group of people [Serbs] and form an in-group, which results in the sense of solidarity and togetherness of the "we-group." Unfortunately, this leads to the marginalization of "others" [non-Serbs]. During the interview with Hadzifejzovic, Dodik referred to Bakir Izetbegovic, a former Bosniak member of the tripartite presidency, as Hadzifejzovic's president, to which the host responded, "you [Dodik] are mine, he [Izetbegovic] is yours, and we are ours." Dodik replied, "We are neither ours nor yours, we have a clear position in society" (CD, 2016). This shows that Dodik does not want to be associated with people from the $\mathrm{FBiH}$ and that they do not belong to his "we" group. The strategy of positive self-presentation and negative other-presentation is also applied, which often has no explicit referent (De Cillia et al., 1999, p. 163). Dodik's construction of the Serbs' unity and collective past, which he describes as the Serbs' struggle for freedom, their immense sacrifices, and perseverance, not only serves as the positive self-presentation of Serbs but also of Dodik himself. He stated, "I am proud to have lived in a time of its [RS'] creation and its defense. I have tried to do what was the best for my people [Serbs] without hurting others" (RS Day, 2020).

Dodik uses the strategies of perpetuation and justification to highlight the idea of continuity and maintaining Serb identity, which he perceives to be threatened. Moreover, he uses these strategies to defend RS's complex historical narrative. Dodik references the Serbs' past suffering during the First and Second World Wars, and insists that Serbs need their own country because "[w] hen we [Serbs] did not have a state, we were killed." According to him, the RS exists to ensure history does not repeat itself. Dodik calls the last century "the century of Serb suffering" (RS Day, 2017). Thus, he wants this century to be the century of integration and state-building. Dodik emphasizes a common history and uses collec- 
tive memory to create a connection with his constituents and followers. In addition, he applies the strategy of avoidance by using euphemisms. Dodik had previously referred to the Srebrenica incident as "genocide," but he repudiates this now, and calls Srebrenica "a serious ploy by Bosniaks and some members of the international community" (Srna, 2020). He justifies Serb actions by recalling atrocities committed against Serbs for which no one was prosecuted.

Dodik employs the strategies of transformation to discursively modify the meaning of a relatively well-established aspect of national identity into a different one, by using persuasion and argumentation schemes and topoi. The topoi, which are presented as conditional or causal paraphrases (i.e. "if $x$, then $y$ " or " $y$ because $x$ "), can be observed in the discourse about the referendum (y), which Dodik claims was a response, a reaction to Izetbegovic's politics and abuse of power (x). Dodik states that Izetbegovic "assumed that he could, through foreigners, now the courts, create the reality for RS" (CD, 2016). In addition, Dodik uses the topos of comparison between two entities to build rapport and establish credibility among the masses. According to Dodik, the FBiH does not function at all, nor does BiH. Thus, they weigh down RS. Dodik argues, "RS is the only sustainable community in $\mathrm{BiH}$, in an economic, political, and every other sense" (as cited in Weber, 2015, p. 3). The use of topos of threat is observed in Dodik's rhetoric about perceived attempts by Bosniaks and the international community to endanger and undermine Serbs' national identity and demolish RS. Dodik states, "the fight for the RS is not over, since attacks on RS's rights (which were determined by the international DPA), its institutions and its holidays have not stopped" (RS Day, 2018).

Lastly, Dodik applies destructive strategies to target and destroy existing national identities or elements of them. Dodik declares, "we [RS Serbs] are not Bosnian Serbs, we are Serbs, part of a single nation, with one language and culture" (RS Day, 2018). Dodik claims that it would be "best for Bosniaks if we [RS and $\mathrm{FBiH}]$ all went separate ways, had good neighborly relations where no one would interfere in each other's matters" (CD, 2016). This is a rare occasion when Dodik refers to both entities/ethnic groups as "we" but his ultimate goal is to break this "we," which would be the end of $\mathrm{BiH}$ as a country. When asked whether $\mathrm{BiH}$ will survive in the current condition, Dodik answered, "no, not in any condition" (DW, 2017).

The selected interviews portray Dodik's varying views of BiH. During the interview with Hadzifejzovic in 2016, Dodik appeared positive and 
claimed he was for a "viable" BiH. However, Dodik's rhetoric significantly changed during the interview with Ilic and Bahri in 2017, when Dodik made several bellicose statements, including blatantly calling $\mathrm{BiH}$ a "failed state." He galvanized interviewers by redrawing borders on the map, uniting RS with Serbia, and dividing the rest of $\mathrm{BiH}$ into Bosnian and Croat parts. Although Dodik is known for being a political firebrand who flirted with RS secession before, this was the most egregious act Dodik perpetrated during the interview. Lastly, Dodik angrily talked about $\mathrm{BiH}$ with Maric stating, "I do not love it $[\mathrm{BiH}]$; I think it is a mistake, a historical one. It cannot exist" (Cirilica, 2018). However, what sets this interview apart from the others is Dodik's tendency to keep referring to the suffering of Serbs during the First and Second World Wars and his contempt for the international community. Moreover, Dodik stressed religious differences, accusing Bosniaks of terrorism and Great Britain of working against $\mathrm{RS}$ and helping $\mathrm{BiH}$ become a centralized state. The discourse of difference, used to portray differences between two entities and ethnic groups in $\mathrm{BiH}$, as well as similarities with Serbia is overemphasized.

\section{Discussion on the results of the analysis: prevailing topics and their interdiscursivity}

The present study shows the importance of analyzing Dodik's rhetoric in order to better understand his political agenda and ideology and how he uses identity politics to achieve his goals. As Wodak (2016) points out, discourses are open and hybrid in nature. Thus, when analyzing Dodik's rhetoric about $\mathrm{BiH}$ and its future, other subtopics emerged which showed interdiscursivity between different discourses. For example, the discourse on the RS Day referendum also referred to topics of other discourses (e.g. secession, NATO and EU integration, the view of the international community, etc.). Thus, it is helpful to delve deeper into those topics.

\section{The referendum on the national holiday of RS, January 9}

Referendums often originate in conscious political decisions made by a party, an organization, or a group (LeDuc, 2000, p. 5). In Janu- 
ary 2010, the RS Assembly adopted a new constitutional law on holding referendums (Toal, 2013, p. 168). Dodik has advocated for various referendums since 2003 (e.g. referendums on defense reform, police reform, NATO membership, the OHR's decision regarding the mandates of foreign judges and prosecutors) (Toal and Maksic, 2011, pp. 279-293). Dodik pushed for a referendum on RS Day and justified it as a legitimate political discourse, an answer and reaction to unsuccessful constitutional changes.

By holding the referendum on September 25, 2016, the RS defied the Constitutional Court of $\mathrm{BiH}$, which declared the holiday unconstitutional after reviewing the claim and stated that "each determination of holidays of an entity which symbolizes only one or only two of the three constituent peoples in $\mathrm{BiH}$ represents a measure which leads to division, exclusion, limitation or favoritism based on national or ethnic heritage" (Sluzbeni Glasnik, 2015, p. 114). In addition, since the holiday coincides with a Serbian Orthodox religious holiday, it discriminates against people of other ethnic and religious backgrounds.

The referendum highlighted BiH's ongoing political paralysis and the weakness, inability, and reluctance of both the state and international community to prevent it. This may embolden Dodik to use referendums in the future to defy BiH's laws and the international community. He described the referendum as a magnificent victory that demonstrated Serb energy to everyone, and their ability to organize themselves. Dodik stressed that the referendum represents the rights of the RS and was a tool to defend Serb rights and freedom. He stated, "the people need to get used to going to referendums. If we had not had the referendum, we would have been perceived as weak; the referendum makes us appear stronger and more important... The referendum is the expression of our commitment; it is very legitimate and fair" (Alternativna TV, 2016).

Although Dodik maintained that the referendum was not about status or secession, he implied that the question of RS status might not be off the table in the future (Slobodna Evropa, 2016). According to Dodik, "no body, no institution in the RS, has an independence referendum on its agenda" (DW, 2017). However, he "dreams about it [independence]" (DW, 2017). Dodik states that the right to referendum, as a reflection of "national sovereignty," cannot be denied to "them" [Serbs]. Once again, Dodik uses constructive strategies (national identity, "us" vs. "them") together with the strategies of perpetuation and justification in order to stress the importance of referendums for RS. 
Referendums may have become Dodik's latest tool in the fray for RS's secession.

\section{Secession}

The referendum on January 9, RS Day, had a deeper meaning than just being about a national holiday, because on January 9, 1992, the Bosnian Serb Assembly proclaimed the Serbian Republic of $\mathrm{BiH}$, which was later renamed RS. Thus, the referendum was entwined with a discourse on RS secession, independence and its national identity. When asked whether the map of the Balkans will look the same in ten years, Dodik quickly redrew the borders, joining RS and the northern part of Kosovo with Serbia. He stated, "[t]his is very nice. Here would be that, what you call it... Bosnia, and here would be Herceg-Bosna," for which, Dodik said "let it [Herceg-Bosna] stay alone. We will also remain independent; we [RS] have no intention of abolishing ourselves and joining Serbia. RS will remain - like Vojvodina, so RS can do it as well" (DW, 2017). While this statement at first seems contradictory to Dodik's rhetoric about uniting RS with Serbia, this statement shows that he has considered RS having the same status as Vojvodina, which would still allow him to keep a high ranking political position. In the interview with Hadzifejzovic in 2016, Dodik said that he "might" be the president of RS again in the future.

Dodik argues that "[ $t$ ]hey [Bosniaks and the members of international community] forbid us [Serbs] to dream, to live, to have a republic, and we [Serbs] tell them, we will live, we will dream, and we will become what we want." He further adds, "[w]e dream to be united with motherland Serbia" (RS Day, 2017). Dodik portrays Serbs as oppressed people in $\mathrm{BiH}$, entitled to self-determination. According to Dodik, "[t]he Serbs today have two states. One is Serbia and the other is RS. Although others deny it, today we live in our own state. We see RS as our own state" (RS Day, 2020). He argues that, in order for RS to be able to secede from $\mathrm{BiH}$, it needs a political framework which would be accepted by "some" (assumed to be countries that might support RS secession). Dodik further elaborates by stating that RS has been placed on the geographical and political maps of the world. In his speeches, Dodik references RS's people, territory, institutions, rule of law, common culture, language and history. Hence, if RS is to be recognized as a state, Dodik knows it also needs sovereignty. 


\section{Dodik's relations with the "international community," Serbia and Russia}

Dodik's rhetoric on the international community is constructed in antagonistic relation to RS and the Serbs. He refers to the international community (i.e. the U.S., the EU, and Great Britain) as "a deceitful partner because everything has been created to the detriment of the RS" (Vecernji list, 2017). Not only did Dodik begin using the "us-versus-them" deixis when talking about other ethnic groups in $\mathrm{BiH}$, but also when referring to some members of the international community.

Dodik has expressed the danger for Serbs from what he calls the Bosniak - Office of the High Representative (OHR) dictatorship stating, "I can and will talk, but cannot and will not just listen and nod my head" (as cited in Toal, 2013, p. 178). He claims that the international community has blacklisted Serbs and has worked on weakening the RS by having a closer relationship with Bosnians and stealthily transforming $\mathrm{BiH}$ into a centralized state. Moreover, Dodik accused the foreign judges from the Constitution Court of making political decisions together with Bosnians to the RS's detriment. Thus, Dodik tells Serbs they need to be able to respond to any future attacks and defend themselves and their rights (RS Day, 2017).

On the other hand, Dodik has continued to act in concert with Serbia and Russia. Dodik claims that apart from Serbs who live in the RS, only Serbia and "friendly" Russia wanted the RS to exist, while many from the West did not (RS Day, 2020). Dodik justifies RS's close relationship with Serbia by citing DPA's Article III, which states that "the Entities shall have the right to establish special parallel relationships with neighboring states consistent with the sovereignty and territorial integrity of BiH" (U.S. Department of State, 1995). During his speech on the RS Day in 2017, Dodik expressed his gratitude to Serbia and stated, "our [Serbs'] dream is to have an even closer bond between RS and Republic of Serbia." Later, Dodik stated, "Serbian people are unique and indivisible in national, linguistic and cultural terms... Serbia is our foundation and our love for it [Serbia] should not bother anyone." Dodik added, "the Serb people have two states - Serbia and RS - and we want to be one" (RS Day 2018). This statement can be considered a threat to BiH's territorial integrity. Dodik pledged his allegiance to Serbia, not $\mathrm{BiH}$ and ended his speech with: "Happy RS Day, long live RS, long live Serbia and all Serbian people and all citizens of RS" (RS Day, 2018). In 2020, Dodik excluded the non-Serb population of RS in his address by saying "Long live RS. Long live Serbia and all Serbs wherever 
they are" (RS Day, 2020). In addition, Dodik stressed the importance of the Declaration on the Unity of the Serbian people as a single national framework since "Serbia is the epicenter of all our thoughts, all of our desires" (Cirilica, 2018). After winning the election in 2018, Dodik showed no interest in political solidarity with the other two members of BiH's presidency. Instead, Dodik discussed future cooperation with Serbia and his plans to meet with the president of Serbia before meeting with the other members of BiH's presidency.

Dodik praises Russia for its friendship and economic cooperation with RS. He portrays Russia as RS's guardian, since it vetoed the UN Security Council resolution that was to confirm the Hague's ruling on Srebrenica as genocide. One can argue that there is a quid pro quo built into the RussiaRS relationship: the quid of Russia's support for RS's future plans and veto at the UN Security Council for the quo of exerting its own influence in the region over the West, and stalling NATO and EU enlargement. Although Dodik denies it, Russia may exert considerable influence on his and RS's political agenda. Thus, Dodik's goal might be to stymie BiH's progress towards NATO and EU integration and instead move closer to Russia.

\section{Conclusion}

In the present study, the DHA approach has uncovered the identity formation of democratic antagonism. $\mathrm{BiH}$, with its complicated institutional set up and the political system that appears to be an ethno-national system, allows political elites with different aspirations to maintain power by using nationalist rhetoric. The article examined Dodik's intermediate language in order to uncover the broader sociopolitical and historical context of the emerging topics. The selected interviews and formal speeches were used to examine the coherence of Dodik's rhetoric in emerging topics. Dodik's rhetoric, message and intensity varied, depended on the interviewers and changed over time. For example, Dodik claimed that "we [Serbs] do not have a hidden agenda... Serbs do not have long term goals" (DW, 2018). One could argue that Dodik has long term goals (i.e. secession from $\mathrm{BiH}$ and unification with Serbia). Dodik's rhetoric and actions have become more direct and audacious, especially since his becoming a member of the tripartite presidency of $\mathrm{BiH}$ in 2018.

Milorad Dodik has dominated the RS political scene. He uses rhetorical gambits and engages in identity politics to appeal to Serbs, the 
preponderant ethnic group in the RS, against other [non-Serbs] groups. The analysis of Dodik's discourse revealed Dodik's self-contradictions and inconsistencies, as well as his ability to consistently use a variety of strategies when speaking about the RS, its identity and how it relates to $\mathrm{BiH}$. Moreover, the analysis revealed the populist and manipulative nature of his discursive practices. He uses insinuations, allusions, and trivializing comparisons. The context of Dodik's discourses was looked at from an intertextual and interdiscursive perspective. Intertextuality detected Dodik's conflicting statements, while interdiscursivity showed that discourse on the referendum regarding January 9, RS Day, was intertwined with the discourse on secession, independence, national identity, and the international community's role and involvement in $\mathrm{BiH}$.

According to Dodik, he supports the idea of a constitutional $\mathrm{BiH}$ as outlined in Dayton, not the one the international community has been trying to create and force on Serbs. However, Dodik has defied the international community, and has been advocating for RS secession from BiH. Dodik has vaguely stated he has been working on creating a political environment conducive to RS secession from BiH. Dodik sounds unrepentant when referring to $\mathrm{BiH}$ as a failed and unviable country. In his speeches, Dodik references his pride towards the RS and Serbs, their struggles, survival and freedom, and the need for their own country and/or unification with Serbia. Dodik describes Serbs as peaceful people who do not want to hurt anyone, but who want their own country which will welcome all people, not just Serbs. However, this would mean splitting $\mathrm{BiH}$, a country that already welcomes all of its citizens, regardless of their ethnicity or religion. He states, " $\mathrm{BiH}$ is not our wish. It is our coercion [by the international community]" (RS Day, 2019). With his rhetoric, Dodik not only portrays his vision and construction of the RS and Serb identity, he also emphasizes his antagonistic relationship with some members of the international community.

During the interviews, and in his speeches at the celebrations of RS Day, Dodik used the "us" versus "them" deixis and differentiated between the identities of RS and $\mathrm{BiH}$. In terms of common history and culture, Dodik associates more with Serbia rather than $\mathrm{BiH}$, which leads to the debate about "national territory" and his desire to merge RS and Serbia. By making this statement, Dodik marginalizes non-Serbs as outsiders who may struggle with the sense of belonging, as their identity is being closely tied to imposed and overemphasized ethnic and religious labels. Dodik's rhetoric poses a real danger and may threaten BiH's sovereignty and territorial integrity, as he may still plan the RS secession and unification of all 
Serbs in one country. He instrumentalizes the past, or his version of it, to portray national victimization, which might serve as a pretext for a political or armed attack on the "other." Dodik plays the ethnic/religious card and tries to rekindle forgotten, or create non-existent grievances. Dodik's rhetoric, more nationalistic by the day, exposes him as a bulwark against a united BiH. Dodik may not be willing to forswear brinkmanship, which, although a gamble, has turned out to be beneficial for him in the past.

After becoming the Serb member of the tripartite presidency of $\mathrm{BiH}$, Dodik stated, "I don't care who the other two representatives in the presidency are. I am going there, to this presidency, to work above all and only for the interests of Serbs" (Lakic, 2018). Dodik has done exactly that thus far, going as far as withdrawing the RS representatives from state institutions, blocking decisions, and causing institutional paralysis. His intransigence may further impede its central institutions and draw $\mathrm{BiH}$ into a political quagmire, making it easier for RS to secede (DW, 2017). Dodik may filibuster to prevent BiH's accession to NATO and EU, which would hold $\mathrm{BiH}$ back from progressing into a stable democracy. He promises to continue to fight for Serb rights and retrieve what was taken from Serbs using political tools (RS Day, 2020). Moreover, Dodik may have other esoteric and potentially insidious plans for $\mathrm{BiH}$, including the secession of RS. Dodik called for a referendum for the umpteenth time, but this would be a referendum on secession with the slogan "Goodbye BiH, welcome RS-exit." Unfortunately, one can argue the plan for the RS-exit has already been put in motion, since Dodik's rhetoric no longer disavows irredentist aspiration. Thus, BiH's future may be replete with Dodik's further attempts to undermine BiH's territorial integrity, canvass greater autonomy for the RS, weaken BiH's already fragile democracy and stall the Euro-Atlantic integrations.

\section{Bibliography}

Alternativna TV, Dodik: Sljedeće godine veoma važan referendum za RS, 29.12.2016, www.atvbl.com/dodik-sljedece-godine-veoma-vazan-referendum-za-rs, 22.05.2019.

Alternativna TV, Dodik: Nemamo namjeru da odustanemo od referenduma, 20.08.2016, www.atvbl.com/dodik-nemamo-namjeru-da-odustanemo-od-referenduma, 31.01.3019.

BN, Milorad Dodik: Ja, nekad i sad, 21.09.2016, BN Televizija, https://www.rtvbn. com/3833897/milorad-dodik-ja-nekad-i-sad, 14.02.2019.

Basseuner K. (2009), Bosnia's Phony Transition: The Mirage of Bosnian Democracy and False Assumptions of the EU, 1989-2009 Years Of Upheaval: Begin- 
ning Of Inclusion or Exclusion, European Integration Between Transition and Identity, Heinrich Böll, Foundation, https://www.boell.de/sites/default/ files/20_years_of_upheaval.pdf.

Barlovac B. Dodik: Republika Srpska Will Be Independent, 05.10.2012, Balkan Transitional Justice, https://balkaninsight.com/2012/10/05/dodik-republikasrpska-will-be-independent/, 08.12.2019.

Benhabib S. (1997), Strange Multiplicities: The Politics of Identity and Difference in a Global Context, "Macalester International", vol. 4.

Bieber F. (2006), Post-War Bosnia. Ethnic Inequalities and Public Sector Governance Series, Palgrave Macmillan, London.

Blommaert J. (2005), Discourse: A Critical Introduction, Cambridge University Press, Cambridge.

Ciepley D. (2013), Dispersed Constituency Democracy: Deterritorializing Representation to Reduce Ethnic Conflict, "Politics \& Society", vol. 41, no. 1.

De Cillia R., Reisigl M., Wodak R. (1999), The discursive construction of national identities, "Discourse \& Society", vol. 10, no. 2.

Dodik M., Svečana akademija povodom 9. Januara - Dana Republike, 09.01.2017, https://www.youtube.com/watch?v=-bAY_U19f4U, 08.08.2019.

Dodik M., Dan Republike Srpske, 09.01.2018, https:/www.youtube.com/ watch? $\mathrm{v}=\mathrm{U} 48 \mathrm{cA} 3 \mathrm{~L} 1 \mathrm{Lr} 0,05.12 .2019$.

Dodik M., Govor na svečanom prijemu, 09.01.2019, https:/www.youtube.com/ watch?v=NfsIDAZPgkY, 12.02.2019.

Dodik M., Srpska je sinonim za slobodu, 09.01.2020, https:/www.youtube.com/ watch? $\mathrm{v}=$ - $4 \mathrm{j}$-dWbUpY8, 12.04.2020.

Gromes T. (2010), Federalism as a Means of Peace-Building: The Case Postwar Bosnia and Herzegovina, "National and Ethnic Politics", vol. 16.

Hadzifejzovic S., Dodik M. (2016), Dodik: Pravim drzavu! Hadzifejzovic: Nece moci bez rata!, 15.10.2016, Centralni Dnevnik, https:/www.youtube.com/ watch? $\mathrm{v}=4 \mathrm{eGGZCe} 6 \mathrm{dQg} \& \mathrm{t}=28 \mathrm{~s}, 19.02 .2019$.

Holbrooke R. (1999), To End a War, Modern Library, New York.

Ilic Z., Cani B. (2017), Kako Dodik Crta Granicu, 20.11.2017, Deutsche Welle, https: //www.dw.com/sr/kako-dodik-crta-mapu/av-41448864, 20.12.2018.

IndexHr, Dodik: BiH za Srbe ne predstavlja ništa, naša država je Republika Srpska, 13.09.2018, https://www.index.hr/vijesti/clanak/dodik-bih-za-srbe-ne-predstavlja-nista-nasa-drzava-je-republika-srpska/2023584.aspx, 12.04.2019.

Ivanji A., Intervju - Milorad Dodik: Federacija je inostranstvo, 19.02.2009, Vreme, https:/www.vreme.com/cms/view.php?id=825137\&print=yes, 12.05.2019.

Jeffries I. (2002), The Former Yugoslavia at the Turn of the Twenty-First Century: $A$ Guide to the Economies in Transition, Routledge, London.

Karabegovic D., Dodik M. (2016), Dodik o Referendumu sa Putinom, 19.09.2016, Radio Slobodna Evropa, https://www.slobodnaevropa.org/a/28000562.html, 13.06.2019. 
Lakic M., Serbian Hardliners Claim Victory in Bosnian Elections, 08.10.2018, Balkan Insight, https://balkaninsight.com/2018/10/08/new-names-in-bosnianpresidency-names-declared-10-08-2018/, 01.03.2019.

LeDuc L. (2000), Referendums and Elections: How Do Campaigns Differ?, University of Toronto.

Majstorovic D., Turjacanin V. (2013), Youth Ethnic and National Identity in Bosnia and Herzegovina: Social Sciences Approaches, Palgrave Macmillan, UK.

Maksic A. (2009), Referendum Discourse in Republic of Srpska Politics 2006-2008: An Analysis of its Emergence and Performative Structure, Virginia Tech University.

Maric M., Dodik M. (2018), Predsednik Republike Srpske, 23.01.2018, Cirilica, https://www.youtube.com/watch?v=Y8q5Ddsf2b0\&t=600s, 10.12.2018.

Parish M., Milorad Dodik and the Politics of Referendum, 16.05.2011, Transconflict, http://www.transconflict.com/2011/05/milorad-dodik-and-the-politics-of-referendum-165, 23.10.2019.

Rabushka A., Shepsle K. A. (1972), Politics in Plural Societies: A Theory of Democratic Instability, Charles E. Merrill Publishing Company, Columbus.

Reisigl M., Wodak R. (2001), Discourse and Discrimination: Rhetoric of Racism and Antisemitism, Routledge, New York-London.

Sarajevo Times, Milorad Dodik is Official Candidate for a Member of BiH Presidency, 30.05.2018, https://www.sarajevotimes.com/milorad-dodik-is-officialcandidate-for-a-member-of-bih-presidency/, 08.12.2019.

Sluzbeni Glasnik BiH, Odluka o dopustivosti i meritumu, 29.12.2015, http://sllist.ba/ glasnik/2015/broj100/Broj100.pdf, 12.04.2020.

Srna, Dodik: Srebrenica je ozbiljna podvala Bosnjaka i dijela medjunarodne zajednice, 02.02.2020, SrpskaInfo,https://srpskainfo.com/dodik-srebrenica-je-ozbiljna-podvala-bosnjaka-i-dijela-medjunarodne-zajednice/, 01.03.2020.

Toal G. (2013), Republika Srpska will Have a Referendum: the Rhetorical Politics of Milorad Dodik, "Nationalities Papers: The Journal of Nationalism and Ethnicity", vol. 41, no. 1 .

Toal G., Maksić A. (2011), Is Bosnia-Herzegovina Unsustainable? Implications for the Balkans and European Union, "Eurasian Geography and Economics", vol. 52 , no. 2 .

U.S. Department of State, The General Framework Agreement for Peace in BiH: Annex 4 - Constitution, 21.11.1995, https:/www.state.gov/p/eur/rls/or/dayton/, 10.08.2019.

Van Leeuwen T., Wodak R. (1999), Legitimizing Immigration Control: A DiscourseHistorical Analysis, "Discourse Studies", vol. 1, no. 1.

Vujanovic D., Uz Srbiju smo i kad gresi, 27.07.2010, Novosti, https://www.novosti.rs/vesti/naslovna/aktuelno.69.html:294092-Uz-Srbiju-smo-i-kad-gresi, 19.02.2020.

Vecernji.ba, Dodik oporbi: Samo recite da hocete i idemo u referendum!, 06.11.2017, Vecernji List, https://www.vecernji.ba/vijesti/dodik-oporbi-samo-recite-dahocete-i-idemo-u-referendum-1205888, 14.07.2019. 
Walker M. C. (2003), The Strategic Use of Referendums: Power, Legitimacy, and Democracy, Palgrave Macmillan, New York.

Weber B. (2015), Inflammatory political rhetoric and hate speech in BiH: political elites and the media, Democratization Policy Council \& Atlantic Initiative, Security Risk Analysis Paper Series 1.

Wodak R., de Cellia R., Reisigl M., Liebhart K. (1999), The Discursive Construction of National Identity, Edinburgh University Press, Edinburgh.

Wodak R. (2001), The Discourse-Historical Approach, in: Methods of Critical Discourse Analysis, eds. R. Wodak, M. Meyer, SAGE Publications, LondonThousand Oaks-New Delhi, pp. 63-95.

Wodak R. (2009), The semiotics of racism: A critical discourse-historical analysis. Discourse, of course: an overview of research in discourse studies, ed. J. Renkema, Benjamins, Amsterdam.

Wodak R. (2016), "We have the character of an island nation" A discourse-historical analysis of David Cameron's "Bloomberg Speech" on the EU, "SSRN Electronic Journal".

\section{Kontrowersyjna retoryka Milorada Dodika w (de)konstrukcji tożsamości Bośni i Hercegowiny. Analiza historyczno-dyskursywna}

\section{Streszczenie}

Ten artykuł bada dyskurs polityczny Milorada Dodika, obecnego serbskiego członka trójstronnej prezydencji w Bośni i Hercegowinie $(\mathrm{BiH})$, i zwraca uwagę na zawiłości jego polityki. Analizuje szereg wywiadów telewizyjnych z Miloradem Dodikiem i przemówienia, które wygłosił podczas uroczystości 9 stycznia $2017 \mathrm{r}$. Niestety, BiH nadal zmaga się z dzielącą polityką tożsamości, która utrwala nacjonalistyczny paradygmat narodu. Polityka tożsamości odgrywa integralną rolę w konstruowaniu „my” kontra „oni” i leży u podstaw braku „tożsamości narodowej”. Analiza ujawnia strategie polityczne Dodika i zwraca uwagę na jego ideologię i poglądy na $\mathrm{BiH}$, a także na jego wizję i długoterminowe cele dla RS. Nadto, ujawnia polityczny cel tych wywiadów i przemówień. Artykuł analizuje praktyki językowe i stara się odpowiedzieć na następujące pytania badawcze: Jak Dodik postrzega BiH i jakie są jego długoterminowe cele w RS? Czy polityka tożsamości wpłynęła na przeprowadzenie referendów w RS? Jaki wpływ na przyszłość BiH i jej tożsamość narodową mogą mieć zaproponowane i przeprowadzone referenda?

Słowa kluczowe: referendum, tożsamość narodowa, polityka tożsamości, analiza historyczno-dyskursywna, Bośnia i Hercegowina, Milorad Dodik 